\section{Prevalence and diversity of Arcobacter spp. in retail chicken meat in Turkey}

\author{
Celenk Molva, ${ }^{1}$ Halil Ibrahim Atabay ${ }^{1,2}$ \\ 'Department of Food Engineering, Izmir \\ Institute of Technology; ${ }^{2}$ Department of \\ Medical Microbiology, Faculty of \\ Medicine, Sifa University, Izmir, Turkey
}

been observed for poultry, followed by pork and beef meat. ${ }^{10}$ If contaminated foods or water is consumed, the infection can occur. ${ }^{11}$

There are various studies about the isolation of Arcobacter spp. from chicken. ${ }^{12-19}$ Although gastroenteritis associated with Arcobacter spp. is a serious problem for human, there are only a few studies in Turkey studied its occurrence in food and water. ${ }^{20-22}$ Therefore, the main objective of this study was to determine the prevalence and diversity of Arcobacter spp. in chicken samples using molecular methods.

\section{Abstract}

Arcobacters are food and waterborne pathogens associated with human and animal infections. The objective of the present study was to investigate the prevalence and diversity of Arcobacter spp. in commercially sold chicken meat in İmir region of Turkey. For this purpose, 100 samples including legs $(n=40), 17$ chicken quarters $(\mathrm{n}=17)$, drumstickers $(n=16)$, breasts $(n=11)$, wings $(n=10)$, and carcasses $(n=6)$ were collected from different retail markets. A total of 65 isolates were confirmed as Arcobacter spp. from 55 samples by genus-specific polymerase chain reaction (PCR). The prevalence of Arcobacter spp. was $32.5,81.3,64.7,72.7,83.3$, and $50 \%$ for legs, drumstickers, chicken quarters, breasts, carcasses and wings, respectively. Based on the multiplex-PCR, most of the isolates were identified as $A$. butzleri $(\mathrm{n}=45,80 \%)$, followed by $A$. cryaerophilus $(\mathrm{n}=2,3.6 \%)$, A. skirrowii $(\mathrm{n}=1$, $1.8 \%)$ and 17 isolates (30.9\%) could not be identified at the species level.

\section{Introduction}

Contamination of poultry meat and its products with the emerging human pathogens such as Campylobacter and Arcobacter spp. poses a potential risk for the microbiological safety. ${ }^{1}$ Arcobacters are characterized as Gram-negative, fastidious, microaerophilic, non-spore forming, usually motile, spiral-shaped bacteria. This genus belongs to the Campylobacteraceae family ${ }^{2}$ and currently comprises 21 species. ${ }^{3}$ These organisms differ from closely related campylobacters by their ability to have aerotolerance and survival capacity at lower temperatures., ${ }^{4,5}$

Pork, beef, lamb, raw milk and shellfish are the foods of animal origin that are used to recover Arcobacter species. ${ }^{6-8}$ A. butzleri, A. cryaerophilus and A. skirrowii are known as the most important species causing infections in humans and animals. ${ }^{6,9}$ In the related literature, the highest prevalence has

\section{Materials and Methods}

\section{Bacterial strains}

The bacterial reference strains $A$. butzleri (LMG 10828), A. cryaerophilus 1A (LMG 9904) and 1B (LMG 10229), and A. skirrowii (LMG 6621) were kindly provided by Maria José Figueras (University of Rovira I Virgili, Spain).

Samples used in this study [legs $(n=40)$, chicken quarters $(\mathrm{n}=17)$, drumstickers $(\mathrm{n}=16)$, breasts $(n=11)$, wings $(n=10)$, and carcasses $(n=6)]$ were collected from a number of retail supermarkets in İzmir, Turkey. All samples were transported to the laboratory immediately, kept cool and analyzed within $24 \mathrm{~h}$.

\section{Isolation}

Each sample (10 g) was homogenized for 1$2 \mathrm{~min}$ in $90 \mathrm{~mL}$ of sterile buffered peptone (Oxoid CM0509, UK). Then, an aliquot of the homogenate $(10 \mathrm{~mL})$ was inoculated into equal volume of double strength Arcobacter broth (Oxoid CM965, UK) containing cefoperazone-amphotericin B-teicoplanin selective supplement (CAT, 0xoid SR174E, UK). This suspension was incubated microaerobically for $48 \mathrm{~h}$ (Anoxomat Mart II Microbiology, The Netherlands) at $30^{\circ} \mathrm{C}$. After enrichment, the sample $(100 \mu \mathrm{L})$ was filtered using $0.45-\mu \mathrm{m}$ pore size nitrocellulose membrane filters (Millipore HAWG047S1, USA) onto the modified charcoal cefoperazone deoxycholate agar (mCCDA, 0xoid CM739, UK). After incubation at $30^{\circ} \mathrm{C}$ for $45 \mathrm{~min}$, the filtrate was streaked onto mCCDA plates. Finally, the plates were incubated at $30^{\circ} \mathrm{C}$ aerobically for $48 \mathrm{~h}^{12}$ Suspected colonies from each plate were purified by streaking and confirmed by Gram-staining, oxidase tests (Merck 1.13300, Germany), and motility under phase contrast microscope. The isolates that were Gram-negative, spiralshaped, motile and oxidase-positive isolates were stored in $20 \%(v / v)$ nutrient broth No.2 (Oxoid CM0067, UK)-glycerol (AppliChem A1123, Germany) at $-80^{\circ} \mathrm{C}$.

\section{Sample collection}

Correspondence: Celenk Molva, Department of Food Engineering, Izmir Institute of Technology, Urla, 35430, Izmir, Turkey.

Tel.: +90.2327506276 - Fax: +90.2327506196

E-mail: celenkmolva@gmail.co

Key words: A. butzleri; pathogen; chicken; multiplex-PCR.

Acknowledgments: this study is supported by a research grant from Scientific Research Project from Izmir Institute of Technology (2010iyte06). We would like to thank to the members of the Biotechnology and Bioengineering Research Center of Izmir Institute of Technology.

Contributions: HIA was involved in designing the experiments, CM performed the experimental work; CM and HIA analyzed the results and wrote the manuscript.

Conflict of interest: the authors declare no potential conflict of interest.

Received for publication: 3 May 2015.

Accepted for publication: 7 June 2015.

This work is licensed under a Creative Commons Attribution NonCommercial 4.0 License (CC BYNC 4.0).

(C) Copyright C. Molva and H.I. Atabay, 2016 Licensee PAGEPress, Italy

Microbiology Research 2016; 7:6578

doi:10.4081/mr.2016.6578

\section{Genus-specific polymerase chain reaction}

DNA was extracted using a commercial genomic DNA isolation kit (PureLink ${ }^{\circledR}$ Kit, Invitrogen, Thermo Fisher Scientific, USA). The primers of Harmon and Wesley $(1996)^{23}$ were used for genus-specific polymerase chain reaction (PCR). The reaction was performed in a total volume of $25 \mu \mathrm{L}$ containing $2 \mu \mathrm{L}$ template DNA, $2.5 \mu \mathrm{L}$ of $10 \times \mathrm{PCR}$ buffer $(750$ $\mathrm{mmol} / \mathrm{L}$ Tris-HCl (pH 8.8), $200 \mathrm{mmol} / \mathrm{L}$ $\left(\mathrm{NH}_{4}\right)_{2} \mathrm{SO}_{4}, 0.1 \%(v / v)$ Tween 20, and 1.5 $\mathrm{mmol} / \mathrm{L} \mathrm{MgCl}_{2}$ ), $10 \mu \mathrm{mol} / \mathrm{L}$ of each of the primers, $0.2 \mathrm{mmol} / \mathrm{L}$ each of the four dNTPs (Fermentas, Thermo Fisher Scientific, USA) and 1.5 U Taq DNA polymerase (Fermentas, Thermo Fisher Scientific, USA). The samples were subjected to an initial denaturation step $\left(94^{\circ} \mathrm{C}\right.$ for $\left.5 \mathrm{~min}\right)$, followed by 35 amplification cycles. Each amplification cycle consisted of 1 min at $94^{\circ} \mathrm{C}$ (denaturation), $1 \mathrm{~min}$ at $56^{\circ} \mathrm{C}$ (primer annealing), and $1 \mathrm{~min}$ at $72^{\circ} \mathrm{C}$ (primer extension). A primer extension step $\left(72^{\circ} \mathrm{C}\right.$ for $7 \mathrm{~min}$ ) followed the final amplification cycle. PCR experiments were repeated twice for each strain. The amplified products were resolved in $1 \%(w / v)$ Tris-acetate-EDTA (TAE) agarose gel and the band patterns were analyzed in the gel 
documentation system (Vilber Lourmat, France). DNA from reference strains were used as positive controls and sterile distilled water served as negative control.

\section{Multiplex-PCR}

The isolates identified as Arcobacter spp. were examined by m-PCR using the primers developed by Houf and colleagues. ${ }^{24}$ PCR reactions were performed in a $25 \mu \mathrm{L}$ reaction mixture containing $2 \mu \mathrm{L}$ template DNA, $2.5 \mu \mathrm{L}$ of $10 \times$ PCR buffer $(750 \mathrm{mmol} / \mathrm{L}$ Tris-HCl (pH 8.8), $200 \mathrm{mmol} / \mathrm{L}\left(\mathrm{NH}_{4}\right)_{2} \mathrm{SO}_{4}, 0.1 \%(v / v)$ Tween 20, and $1.5 \mathrm{mmol} / \mathrm{L} \mathrm{MgCl}_{2}$ ), $10 \mu \mathrm{mol} / \mathrm{L}$ of each of the primers, $0.2 \mathrm{mmol} / \mathrm{L}$ each of the four dNTPs (Fermentas, Thermo Fisher Scientific, USA) and 1.0 U Taq DNA polymerase (Fermentas, Thermo Fisher Scientific, USA). PCR involved initial denaturation at $94^{\circ} \mathrm{C}$ for $3 \mathrm{~min}, 35$ cycles of denaturation $\left(94^{\circ} \mathrm{C}, 45 \mathrm{~s}\right)$, primer annealing $\left(60^{\circ} \mathrm{C}, 45 \mathrm{~s}\right)$ and chain extension $\left(72^{\circ} \mathrm{C}, 1 \mathrm{~min}\right)$, and final extension $\left(72^{\circ} \mathrm{C}, 7\right.$ min). The amplified products were resolved in $1 \%(w / v)$ TAE agarose gel and the band patterns were analyzed in the gel documentation system (Vilber Lourmat, France). DNA from reference strains were used as positive controls and sterile distilled water was used as negative control.

\section{Results and Discussion}

Since it is difficult to identify Arcobacter species using cultural methods, molecular detection and identification methods have been developed for Arcobacter spp. ${ }^{25}$ In the present study, we determined the prevalence and diversity of Arcobacter spp. in chicken samples collected from İzmir region of Turkey by PCR-based methods.

Based on the genus-specific PCR, 65 isolates were identified as Arcobacter spp. among 100 samples analyzed (Table 1). In total, 55 samples were positive for the presence of
Arcobacter spp. (55\%). The highest occurrence was obtained in carcasses $(\mathrm{n}=5,83.3 \%)$, followed by drumstickers $(\mathrm{n}=13,81.3 \%)$, breasts $(\mathrm{n}=8,72.7 \%)$, leg quarters $(\mathrm{n}=11,64.7 \%)$, wings $(n=5,50 \%)$ and legs $(n=13,32.5 \%)$. Studies indicated that the prevalence of Arcobacter spp. in poultry ranged from 38.4 to $90.6 \%$ and the overall prevalence (55\%) obtained in this study was found within this range. ${ }^{26}$ The obtained variations in isolation rates may be related to plant conditions, processing procedure, geographical location, seasonal differences, experimental designs and analytical methods used to analyze the collected samples. ${ }^{14,26}$ As an example, Levican and colleagues $^{8}$ suggested that different conditions used for culturing can lead to different isolation rates. They found that the recovery rate of Arcobacter under aerobic incubation was higher (41.1\%) than that of microaerobic conditions (23.2\%).

Arcobacter spp. has been reported to be as a significant hazard for the public health. ${ }^{26,27}$ Their presence in food processing environments indicates possible persistence or crosscontamination. ${ }^{28}$ The occurrence in poultry carcasses can be due to fecal contamination ${ }^{29}$ or other possible transmission routes during handling (water, processing environment, equipment, feathers) or early stages of processing. ${ }^{30-32}$ In fact, Arcobacter spp. can persist and form biofilms on many pipe surfaces made of steel, copper and polyethylene resulting in colonization in water distribution systems. ${ }^{33}$ In a recent study, processing water and equipment used in the slaughterhouse were suggested as the main sources of broiler carcass contamination by Arcobacter. ${ }^{34}$

The isolated Arcobacter species were further examined by m-PCR to identify at the species level. Based on the m-PCR, the most prevalent species were $A$. butzleri ( $\mathrm{n}=45)$, followed by $A$. cryaerophilus $(\mathrm{n}=2)$ and $A$. skirrowii $(\mathrm{n}=1)$. The remaining Arcobacter isolates $(n=17)$ could not be identified using the available primers at the species level (Table 1). Collado and colleagues ${ }^{35}$ also showed that these three species were found in the water and shellfish most probably due to sewage outlets and fecal contamination. In accordance with the results of previous studies, ${ }^{13,23} A$. butzleri was the most prevalent species on chicken meat. $A$. butzleri was isolated from all types of samples analyzed. Its isolation rates from wings, breasts, drumstickers, carcasses, legs, breasts, and quarters were $100,87.5,84.6,80,76.9$, and $72.7 \%$, respectively. On the other hand, $A$. cryaerophilus and A. skirrowii were detected on the wings and carcass samples and on the drumsticker, respectively.

In eight analyzed samples, both A. butzleri and other two species were isolated. Similar to this finding, the presence of more than one species in the same sample was reported by other researchers. ${ }^{10,31}$ It has been suggested that lower isolation rates for A. skirrowii may be due to its higher susceptibility to antimicrobials present in selective media used or growth competition favoring other microorganisms. ${ }^{36} \mathrm{~A}$. butzleri has been found to cause enteritis and bacteremia in human ${ }^{37}$ and $A$. cryaerophilus and $A$. skirrowii has been isolated from stool of patients with diarrhea. ${ }^{38-40}$ Since A. butzleri, A. cryaerophilus and A. skirrowii are emerging foodborne pathogens, effective control methods should be applied to prevent Arcobacter spp. contamination during food processing for human health.

\section{Conclusions}

Based on the results, the presence of Arcobacter spp. in chicken meat is a potential risk for human health because the consumption of these contaminated products may cause serious diseases. Therefore, effective control strategies should be applied to prevent their contamination during poultry processing in the food industry.

Table 1. Distribution of Arcobacter spp. based on the type of samples.

\begin{tabular}{|c|c|c|c|c|c|c|}
\hline Type of sample & Samples analyzed & Positive samples (\%) & A. butzleri (\%) & A. cryaerophilus (\%) & A. skirrowii (\%) & Non-identified (\%) \\
\hline Leg & 40 & $13(32.5)$ & $10(76.9)$ & - & - & $4(10)$ \\
\hline Leg quarter & 17 & $11(64.7)$ & $8(72.7)$ & - & - & $6(54.5)$ \\
\hline Drumsticker & 16 & $13(81.3)$ & $11(84.6)$ & - & $1(7.7)$ & $3(23.1)$ \\
\hline Breast & 11 & $8(72.7)$ & $7(87.5)$ & - & - & $3(37.5)$ \\
\hline Wing & 10 & $5(50)$ & $5(100)$ & $1(20)$ & - & - \\
\hline Carcass & 6 & $5(83.3)$ & $4(80)$ & $1(20)$ & - & $1(20)$ \\
\hline Total & 100 & $55(55)$ & $45(80)$ & $2(3.6)$ & $1(1.8)$ & $17(30.9)$ \\
\hline
\end{tabular}




\section{References}

1. Duarte A, Alves AC, Ferreira S, et al. Resveratrol inclusion complexes: antibacterial and anti-biofilm activity against Campylobacter spp. and Arcobacter butzleri. Food Res Int 2015;77:244-50.

2. Sasi Jyothsna TS, Rahul K, Ramaprasad EVV, et al. Arcobacter anaerophilus sp. nov., isolated from an estuarine sediment and emended description of the genus Arcobacter. Int J Syst Evol Microbiol 2013;63:4619-25.

3. Giacometti F, Salas-Mass N, Serraino A, Figueras MJ. Characterization of Arcobacter suis isolated from water buffalo (Bubalus bubalis) milk. Food Microbiol 2015;51:186-91.

4. Vandamme P, Vancanneyt M, Pot B, et al. Polyphasic taxonomic study of the emended genus Arcobacter with Arcobacter butzleri comb. nov and Arcobacter skirrowii sp. nov., an aerotolerant bacterium isolated from veterinary specimens. Int $\mathbf{J}$ Syst Bacteriol 1992;42:344-56.

5. Levican A, Rubio-Arcos S, Martinez-Murcia A, et al. Arcobacter ebronensis sp. nov. and Arcobacter aquimarinus sp. nov., two new species isolated from marine environments. Syst Appl Microbiol 2015;38:30-5.

6. Ho HT, Lipman LJ, Gaastra W. Arcobacter, what is known and unknown about a potential foodborne zoonotic agent! Vet Microbiol 2006;115:1-13.

7. Nieva-Echevarri B, MartinezMalaxetxebarria I, Girbau C, et al. Prevalence and genetic diversity of Arcobacter in food products in the north of Spain. J Food Prot 2013;76:1447-50.

8. Levican A, Collad L, Yustes C, et al. Higher water temperature and incubation under aerobic and microaerobic conditions increase the recovery and diversity of Arcobacter spp. from shellfish. Appl Environ Microbiol 2014;80:385-91.

9. Ferreira S, Queiroz JA, Oleastro M, Domingues FC. Insights in the pathogenesis and resistance of Arcobacter: a review. Crit Rev Microbiol 2015;25:1-20.

10. Van driessche E, Houf K. Discrepancy between the occurrence of Arcobacter in chickens and broiler carcass contamination. Poultry Sci 2007;86:744-51.

11. Shah AH, Saleha AA, Zunita Z, Murugaiyah M. Arcobacter-an emerging threat to animals and animal origin food products? Trends Food Sci Technol 2011;25:225-36.

12. Atabay HI, Corry JE. The prevalence of Campylobacters and Arcobacters in broiler chickens. J Appl Microbiol 1997;83:619-26.

13. González A, Botella S, Montes RM, et al. Direct detection and identification of Arcobacter species by multiplex PCR in chicken and wastewater samples from Spain. J Food Prot 2007;70:341-7.

14. Son I, Englen MD, Berrang ME, et al. Prevalence of Arcobacter and Campylobacter on broiler carcasses during processing. Int $\mathrm{J}$ Food Microbiol 2007;13:16-22.

15. Pejchalová M, Dostalikova E, Slámová M, et al. Prevalence and diversity of Arcobacter spp. in the Czech Republic. J Food Prot 2008;71:719-27.

16. Villalobos EG, Jaramillo HF, Ulate CC, Echandi MLA. Isolation and identification of zoonotic species of genus Arcobacter from chicken viscera obtained from retail distributors of the metropolitan area of San José Costa Rica. J Food Prot 2013;76:879-82.

17. Fallas-Padilla KL, Rodríguez CE, Jaramillo HF, Echandi MLA. Arcobacter comparison of isolation methods, diversity, and potential pathogenic factors in commercially retailed chicken breast meat from Costa Rica. J Food Prot 2014;77:880-4.

18. González I, Fernández S, Garcia T, Mart R. Genus-specific PCR assay for screening Arcobacter spp. in chicken meat. J Sci Food Agric 2014;94:1218-24.

19. Rahimi E. Prevalence and antimicrobial resistance of Arcobacter species isolated from poultry meat in Iran. Br Poultry Sci 2014;55:174-80.

20. Atabay HI, Aydin F, Houf K, et al. The prevalence of Arcobacter spp. sold in retail markets in Turkey, and identification of the isolates using SDS-PAGE. Int $\mathrm{J}$ Food Microbiol 2003;81:21-8.

21. Atabay HI, Unver A, Sahin M, et al. Isolation of Arcobacter species from domestic geese (Anser anser). Vet Microbiol 2008;128:400-5.

22. Çelik E, Ünver A. Isolation and identification of Arcobacter spp. by multiplex PCR from water sources in Kars region. Curr Microbiol 2015;71:546-50.

23. Harmon KM, Wesley IV. Identification of Arcobacter isolates by PCR. Lett Appl Microbiol 1996;23:241-4.

24. Houf K, Tutenel A, de Zutter L, et al. Development of a multiplex PCR assay for the simultaneous detection and identification of Arcobacter butzleri, Arcobacter cryaerophilus and Arcobacter skirrowii. FEMS Microbiol Lett 2000;193:89-94.

25. Collado L, Figueras MJ. Taxonomy, epidemiology and clinical relevance of the genus Arcobacter. Clin Microbiol Rev 2011;24:17492.

26. González I, Garcia T, Fernández S. Current status on Arcobacter research: An update on DNA-based identification and typing methodologies. Food Anal Methods 2012;5:956-68.

27. ICMSF. Microorganisms in Foods. 7. Microbiological Testing in Food Safety Management. International Commission on Microbiological Specifications for Foods.
Kluwer Academic/Plenum Publishers, New York 2002.

28. Hsu TT, Lee J. Global distribution and prevalence of Arcobacter in food and water. Zoonoses Public Hlth 2015;62:579-89.

29. Ho TKH, Lipman LJA, Gaastra W. The introduction of Arcobacter spp. in poultry slaughterhouses. Int J Food Microbiol 2008;125:2239.

30. Harras B, Schwarz S, Wenzel S. Identification and characterization of Arcobacter isolates from broiler by biochemical tests, antimicrobial resistance patterns and plasmid analysis. J Vet Med 1998;45:87-94.

31. Houf K, de Zutter L, Vandamme P. Occurrence and distribution of Arcobacter species in poultry processing. $\mathrm{J}$ Food Prot 2002;65:1233-9.

32. Gude A, Hillman TJ, Helps CR, et al. Ecology of Arcobacter species in chicken rearing and processing. Lett Appl Microbiol 2005;41:82-7.

33. Assanta MA, Roy D, Lemay MJ, Montpetit D. Attachment of Arcobacter butzleri, a new waterborne pathogen, to water distribution pipe surfaces. J Food Prot 2002;65:1240-7.

34. Khoshbakht R, Tabatabaei M, Shirzad Aski H, Seifi S. Occurrence of Arcobacter in Iranian poultry and slaughterhouse samples implicates contamination by processing equipment and procedures. Bri Poultry Sci 2015;55:732-6.

35. Collado L, Guarro J, Figueras MJ. Presence of Arcobacter spp. in environmental waters correlates with high levels of fecal pollution. Environ Microbiol 2008;10:1635-40.

36. Houf K, Devriese LA, De Zutter L, et al. Susceptibility of Arcobacter butzleri, Arcobacter cryaerophilus and Arcobacter skirrowii to antimicrobial agents used in selective media. J Clin Microbiol 2001;39: 1654-6.

37. Arguello E, Otto C, Mead P, Babady NE. Bacteremia caused by Arcobacter butzleri in immunocompromised Host: FIG1. J Clin Micro 2015;53:1448-51.

38. Figueras MJ, Levican A, Pujol I, et al. A severe case of persistent diarrhoea associated with Arcobacter cryaerophilus but attributed to Campylobacter sp. and a review of the clinical incidence of Arcobacter spp. New Microbes New Infect 2014;2:31-7.

39. Vanderberg 0, Dediste A, Houf $\mathrm{K}$, et al. Arcobacter species in humans. Emerg Infect Dis 2004;10:1863-7.

40. Wybo I, Breynaert J, Lauwers S, et al. Isolation of Arcobacter skirrowii from a patient with chronic diarrhea. J Clin Microb 2004;42:1851-2. 